\title{
Diet Diversity to Assess Diet Quality of Pre-Conception Women in Bekasi, West Java
}

\author{
Arindah Nur Sartika ${ }^{1}$, Tri Marta Fadhilah ${ }^{1}$ \\ ${ }^{I}$ Nutrition Study Program, Sekolah Tinggi Ilmu Kesehatan Mitra Keluarga, Bekasi, Indonesia \\ Correspondence: arindahns@stikesmitrakeluarga.ac.id
}

\begin{abstract}
Pre-conception women have important role to determine children nutritional status. Children with good nutritional status are born from mothers who have good diet. Diversified diet also can prevent woman to suffer from chronic energy malnutrition and anemia during pregnancy. This study aims to assess diet quality of pre-conception women in Kota Bekasi, West Java. The study conducted as observational study design, specifically using cross sectional approach. About 105 "bride to be" from 8 Religious Affairs Office in Kota Bekasi, West Java, Indonesia was joined the study. Respondents were interviewed with structured questionnaire consist of social economic characteristics and dietary intake. Dietary assessment was done using 24-h food recall to fill Minimum Dietary Diversity for Women of reproductive Age (MDD-W) questionnaire. The result showed out of 10 food groups, median consumption of food groups consumed by respondents was 4 food groups, also as the highest proportion of total food group (36.19\%), followed by 5 food groups (25.71\%), and 3 food groups (21.90\%). Maximum score of dietary diversity is $8(0.95 \%)$, and minimun score is $2(3.81 \%)$. Meanwhile, most consumed food group was staple foods $(99.05 \%)$. Nuts and seeds were the least proportion of food group $(3.81 \%)$ consumed by respondents. There was around one-third $(38.10 \%)$ of the respondents consumed total food group below recommended score $(<5)$. Diet diversity of pre-conception women should be improved. To prevent from malnutrition, pre-conception women are suggested to vary their diet. Nutrition education during premarital class/ consultation is recommended.
\end{abstract}

Keywords: pre-conception women, diet quality, diet diversity. 


\section{INTRODUCTION}

In nutrition life cycle, women of reproductive age (WRA) have important role to prevent malnutrition in other life stages. Malnourished pre-conception women have posibility to be still malnourished during pregnancy. Whereas, women with poor nutritional status will lead to unfavorably pregnancy condition and outcomes. As an example, iron deficiency anemia (IDA) is related to the occurance of gestational hypertension, pre-eclampsia, antepartum hemorrhage, postpartum hemorrhage, transfusion, prolonged/ obstructed labor, urgent induction of labor, urgent caesarean section, low birth weight, and short gestational age (18). In addition, maternal chronic energy deficiency increase also risk of low birth weight (23) Moreover, maternal malnutrition also increases the risk to have malnourished child. Studies proved that stunting also has relationship with maternal nutritional status $(7,10,16)$. Therefore, ensuring good nutritional status among WRA include "bride to be" as preconception women is required, to prevent maternal morbidity and mortality also malnutrition in infants.

Generally, "bride to be" show their interest to have baby after marriage. This aim should be realized with optimal nutritional status. As WRA, their body mass index (BMI) ideally not less than $18.5 \mathrm{~kg} / \mathrm{m}^{2}$ (28). Meanwhile, identification of CED use mid upper arm circumference (MUAC) as an indicator. There are some cut offs used to identify CED, but one of valid cut off already proved $23.5 \mathrm{~cm}$ is the minimum MUAC for WRA (20). WRA is categorized as anemia if haemoglobin level lower than $12 \mathrm{mg} / \mathrm{dL}$ (27). Data from Indonesia Basic Health Survey in 2018, proportion of CED is about $14.5 \%$ and $33.7 \%$ (12). Based on explanation on the first paragraph, these numbers should be lowered since it can determine pregnancy outcome. However, not all WRA or "bride to be" understand about their condition and its implication, so that willing to achieve good nutritional status.

One of keys of achieving optimum nutritional status is obtaining optimum diet. Well-balanced diet should be varied and meet daily requirements. Lower percentage of macro nutrients causes deficiency of energy, and if this condition happens in long period it can lead to CED. Study showed that women with chronic energy malnutrition have strong association with anemia (22). These condition also can be occurred due to poor diet such as undiversified diet and low amount of some food groups.

There are some studies assessing diet quality of women child bearing age. Studies showed that women live in urban do not differ from women live in rural area $(5,19)$. Longitudinal study resulted that overall diet quality of pre-conception women is 
associated with infant birth weight (24). Majority of pre-conceptual and pregnant women also confirmed that they do not meet minimum dietary requirements (4).

Instruments of diet quality assessment can be varied. One of simple instruments that can be used to measure diet quality is dietary diversity. The use of dietary diversity can represent variety of food group consume during a day. Recommended diet should consist of various food groups. Various group eaten during one day can contribute to fulfilment of nutrients, especially micro nutrients. Dietary diversity increases the possibility for different food groups to share its nutrient contents. It also provides healthy phytochemicals that comply daily requirements (17).

A study confirmed that dietary diversity has correlation with Nutrient Adequacy Ratio (NAR) from all of nutrients assessing in the study (protein, fat, calcium, iron, vitamin A, thiamine, riboflavin, niacin, folic acid, vitamin C, and energy). The study using 24-h food recall to assess individual dietary diversity. Dietary diversity also showed linear association with nutritional status of adults. The study also mentioned that $24-\mathrm{h}$ food recall is a recommended tool to measure association of dietary diversity and nutritional outcomes among adults (21). Other study confirmed that women who have higher dietary diversity are showing higher BMI (2).
Dietary diversity as proxy indicator of balanced diet is should be understood well by pre-conception women before pregnancy. Furthermore, understanding of having good nutritional status also necessary. Dietary diversity assessment is suggested to be put on the pre-marital education session. Referring to information above, this study aims to analyse diet diversity of "bride to be" as pre-conception women living in Kota Bekasi, West Java.

\section{METHODS}

This research was observational study, with cross sectional design. It was conducted in March to May 2019. Subjects of this research was 105 women who registered their marriage plan at 8 "Kantor Urusan Agama” (Religious Affair Offices), Bekasi, West Java. Location mentioned in the study were KUA Mustika Jaya, KUA Bantar Gebang, KUA Jati Sampirna, KUA Jati Asih, KUA Pondok Melati, KUA Medan Satria, KUA Bekasi Utara, and KUA Bekasi Selatan. Criteria of subjects are: 1) Women aged 20-40 years; 2) First marriage; 3) Do not have changes diet in the last three months due to (acute) disease. Data collection was conducted using direct interview. Data collected were subject characteristics, nutritional status, and dietary intake. 
Subject characteristics asked in the study were age, education, and occupation. Dietary intake was obtained using repeated 24-h food recall. Dietary data collected to assess diversity of the respondents using Minimum Dietary Diversity for Women of reproductive Age (MDD-W) (FAO and FHI $360,2016)$. The list of food group consists of: 1) Staple foods, 2) Beans and peas, 3) Nuts and seeds, 4) Dairy, 5) Meat, poultry, and fish, 6) Eggs, 7) Dark green leafy vegetables, 8) Vitamin A rich fruits and vegetables, 9) Other vegetables, and 10) Other fruits. If the subject consumed certain food group then it was scored by 1 , and 0 for the contrary (not consumed). Later, the total score was calculated as dietary diversity score (numerical data). Cut of good dietary diversity score was equal to or above 5 . Nutritional status determined by anthropometric measurement of MUAC. Respondents were classified into CED if their MUAC was $<23.5 \mathrm{~cm}$, and non-CED was $\geq 23.5 \mathrm{~cm}$. Additional nutritional outcome assessed in the study was BMI. Body weight and height measurement were done by calibrated digital weight scale and microtoise. Classification of BMI were underweight $\left(<18.5 \mathrm{~kg} / \mathrm{m}^{2}\right)$, normal (18.5 $\left.23.0 \mathrm{~kg} / \mathrm{m}^{2}\right)$, and overweight $\left(>23.0 \mathrm{~kg} / \mathrm{m}^{2}\right)$. To avoid bias, trained enumerators under Nutrition Study Program STIKes Mitra Keluarga were involved in the study.
This study already passed ethical clearance from Komisi Etik Universitas Muhammadiyah Dr. Hamka (UHAMKA), Jakarta, Indonesia. Statistical analysis was performed to run univariate and bivariate analysis. To test the difference of diet quality among two nutritional status groups, spearman test was ran.

\section{RESULTS}

Subjects included in the study was pre-conception women, who already registered their marriage plan in the some KUA in Kota Bekasi, West Java. The majority of WRA aged 20-25 years old and work as private employee. More than fifthy respondents was finished secondary education. Nutritional status data showed that majority respondents were non-CED and not consider as underweight. Eventhough, number of CED and underweight was same. Futher statistical analysis found significant correlation between CED and BMI $(p<0.05)$. Distribution of data collection location was nearly similar across KUA. More than fifty percent of women finished secondary education. 
Table 1: Characteristics of respondents joined in dietary diversity study

\begin{tabular}{|c|c|c|}
\hline Variable & N (\%) & $\begin{array}{c}\text { Median } \\
\left(\mathbf{2 5}^{\text {th}}-75^{\text {th }}\right. \\
\text { percentile) }\end{array}$ \\
\hline Age & & $23(22-25)$ \\
\hline$<20$ years & $6(5.7)$ & \\
\hline $20-25$ years & $78(74.3)$ & \\
\hline $25-35$ years & $21(20.0)$ & \\
\hline \multicolumn{3}{|l|}{ Education } \\
\hline Lower education (primary & $7(6.7)$ & \\
\hline school) & $62(59.0)$ & \\
\hline Secondary education & $36(34.4)$ & \\
\hline \multicolumn{3}{|l|}{ (high school) } \\
\hline \multicolumn{3}{|l|}{$\begin{array}{l}\text { Higher education } \\
\text { (university/vocational school) }\end{array}$} \\
\hline \multicolumn{3}{|l|}{ Occupation } \\
\hline Do not work & $14(13.3)$ & \\
\hline Labour/farmer & $\begin{array}{c}6(5.7) \\
17(16.2)\end{array}$ & \\
\hline Entrepreneur/seller/service & $63(60.0)$ & \\
\hline Private employee & $5(4.8)$ & \\
\hline Government & & \\
\hline \multicolumn{3}{|l|}{ officer/police/soldier } \\
\hline \multicolumn{3}{|l|}{ Location of KUA } \\
\hline Mustika Jaya & $20(19.0)$ & \\
\hline Bantar Gebang & $14(13.3)$ & \\
\hline Jati Sampirna & $10(9.5)$ & \\
\hline Jati Asih & $12(11.4)$ & \\
\hline Pondok Melati & $13(12.4)$ & \\
\hline Medan Satria & $17(16.2)$ & \\
\hline Bekasi Utara & $9(8.6)$ & \\
\hline Bekasi Selatan & $10(9.5)$ & \\
\hline \multicolumn{3}{|l|}{ Status of CED } \\
\hline $\operatorname{CED}(<23.5 \mathrm{~cm})$ & $16(15.2)$ & \\
\hline Non-CED $(\geq 23.5 \mathrm{~cm})$ & $89(84.9)$ & \\
\hline \multicolumn{3}{|l|}{ BMI } \\
\hline Underweight $\left(<18.5 \mathrm{~kg} / \mathrm{m}^{2}\right)$ & $16(15.2)$ & \\
\hline $\operatorname{Normal}\left(18.5-22.9 \mathrm{~kg} / \mathrm{m}^{2}\right)$ & $53(50.2)$ & \\
\hline Overweight $\left(\geq 23 \mathrm{~kg} / \mathrm{m}^{2}\right)$ & $36(34.3)$ & \\
\hline
\end{tabular}

In term of diet diversity, the greatest and the lowest score of dietary diversity was 2 and 8 . However, only $0.95 \%$ showed optimum score of 8 . Score "4" was reported as median score for dietary diversity. Out of 10 food indicators, there was subjects failed to complete recommeded dietary diversity with score " 2 " of dietary diversity. Around $30 \%$ of women showed score of dietary diversity equal to or/and diet $\geq 5$ groups. Meat, poultry, fish was the second most consumed food after staple foods. The smallest consumer was among nuts and seeds group.

Table 2. Percentage of Dietary Diversity Score

\begin{tabular}{cc}
\hline $\begin{array}{c}\text { Score of dietary } \\
\text { diversity }^{*}\end{array}$ & N (\%) \\
\hline 2 & $4(3.81)$ \\
3 & $23(21.90)$ \\
4 & $38(36.19)$ \\
5 & $27(25.71)$ \\
6 & $8(7.62)$ \\
7 & $4(3.81)$ \\
8 & $1(0.95$
\end{tabular}

${ }^{*}$ Score minumum $=0 ;$ scoremaximum $=10 ; \mathrm{N}=105$

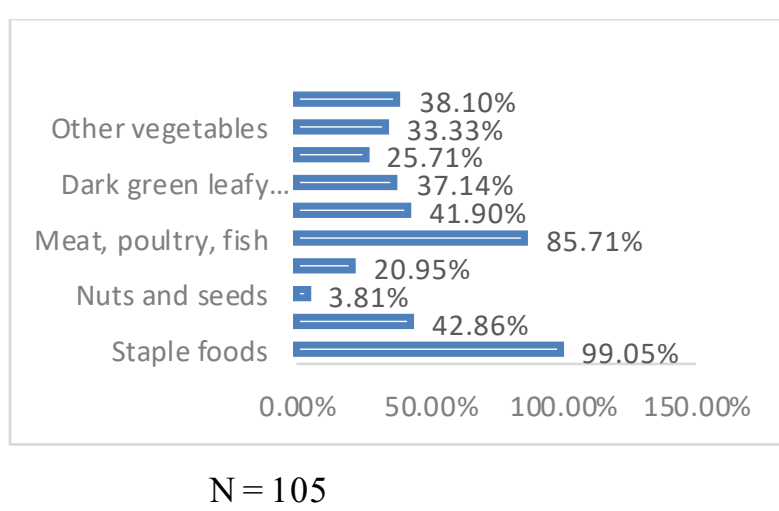

Figure 1. Proportion of food groups consumed by repondents

\section{DISCUSSIONS}

Dietary diversity measurement is one of general instruments to evaluate dietary pattern among women of reproductive age. Other studies also confirmed the association of MDD-W and other variables such as food insecurity, educational level, living area, and BMI $(1,26)$. During the development of dietary diversity tool assessment, there are other questionnaires with similar approaches and questionnaire used in the study, but showing different amount of food groups. Some studies reported using 6 food 
gsroups, 9 food groups, 13 food groups, 16 food groups, until 21 food groups $(6,8,11)$. MDD-W is reported as a updated and valid instrument to assess women targeted studies(9).

Based on the study result, no subjects reported can obtain perfect score. Staple food group was most consumed category. Almost all respondents ate rice as staple food. From literature, staple foods showed greater contributor for energy, carbohydrate, protein, thiamine, and pyridoxin (3). Enough consumption of this group could prevent chronic energy deficiency, if consumed in adequate intake. Preconception women among younger adults' groups are suggested to take diet more or less $2250 \mathrm{kcal}, 60 \mathrm{~g}$ protein, $360 \mathrm{~g}$ carbohydrate (13). Examples of portion for this age group are carbohydrate and protein from 5 portion of staple foods and 3 portion of animal protein source group, and 3 portion of plant protein source group (15).

While meeting requirements of carbohydrate and protein, WRA should also meet vitamin and mineral allowance. Dark green leafy vegetables are high source of vitamin A. However, WRA in this study showed the low proportion. Dark green leafy vegetables also reported to contribute at least $10 \%$ to following nutrients such as calcium, folate, riboflavin, vitamin $\mathrm{C}$, and iron (3). In Indonesia, the availability of dark green leafy vegetables is common, so
WRA should not find difficulty to get it during meal time. WRA have higher risk to be micronutrients deficiency, thus consumption green leafy vegetables is recommended to prepare iron, folate, and calcium deficiency during pre- pregnancy. Besides consuming dark green leafy vegetables, vitamin $\mathrm{A}$ also can be met by eating fruits and vegetable (with high source of vitamin A). Examples of this food group consumed by subjects of the study are papaya and mango.

Second highest percentage of food group eaten by pre-conception women in this study is flesh food includemeat, chicken, and fish. Almost hundred percent of respondents chose chicken as part of diet during 24 hours. Meat generally consumed as processed food is meat ball and sausages. Fish and seafood mentioned in the study are nila, kembung, mujair, and squids. Adequate consumption of protein source foods can reduce the risk of maternal malnutrition. However, dairy consumption remains lower in the study. Only one to fifth women mentioned milk and dairy products during meal or snacking time. Although showing small percent contribution through many nutrients, dairy consists of all nutrients addressed by literature (8).

Then, about one-third of subjects showed $>5$ food groups, as suggested cut off dietary diversity. This finding is similar with study in Sri Lanka, $36.75 \%$ of subjects have 
score "5 or more" of dietary diversity (26). In the study, maximum score was 8 , but only small percentage of respondents had that score. Eventhough, there was WRA who only consumed 2 food groups. Also, across groups show " 4 " as median score of dietary diversity, which is below the recommended minimum food groups. The smallest percentage of food groups is from nuts and seeds. Data shows that type of nuts and seeds group eaten is peanut butter (in gadogado and ketoprak, both are traditional vegetables salad). Whether, beans and peas consumed are soybean products (soya milk, tempeh, tofu) and mung bean (porridge). Other similar percentage remains among egg group. All respondents confirm chicken eggs as dishes during the day. Unlike previous groups, vegetables and fruits consumption also remain small proportion.

In the result, more than half of respondents do not take vegetables and/or fruits. This data is supported by Indonesia Basic Health Survey (Riskesdas) in 2013 and $2018(12,14)$. Nationally, more than 90\% Indonesian do not meet daily recommendation of vegetables and fruits. This condition has to be eliminated since lower consumption of vegetables and fruits relate to many disadvantages. In the opposite, regular consumption of fruits and vegetables has many benefit to human health. Higher fruits and vegetables intake can prevent from several non-communicable diseases such as cancer, obesity, cardiovascular, cognitive, skin, eyes, lung, and bone disease (29).

\section{CONCLUSION}

The study conclude that not all preconception women from 9 KUA in Kota Bekasi show optimum diet diversity. Only $38,1 \%$ women consumed 5 food groups per day. Maximum score of dietary diversity is $8(0.95 \%)$, and minimun score is $2(3.81 \%)$. Diet diversity of pre-conception women should be improved. To prevent from malnutrition, pre-conception women are suggested to vary their diet. Nutrition education during premarital class/ consultation is recommended. Others from the study, there are some limitiation that should be fixed or added in another research. This research did not combine analysis of dietary diversity with other instruments to assess quality of diet. Therefore, it is suggested to conduct future research with including other diet quality indicators/indices. So, researchers can explain more data about subjects' diet and prove some theories. As an example, researchers run analysis for quantity of nutrients intake, the adequacy, diversity of food consumption, energy density, and other indicators or indices that can be performed to measure diet. 


\section{ACKNOWLEDGEMENT}

We acknowledge to STIKes Mitra

Keluarga who supported this study from the begining till the end. Also, we honour Ministry of Religious Affair Kota Bekasi for giving research official permission, especially for $9 \mathrm{KUA}$ in Kota Bekasi. We appreciate the cooperation of KUA officers and "bride to be" in the sub-districts of Mustika Jaya, Bantar Gebang, Jati Sampurna, Jati Asih, Pondok Melati, Medan Satria, Bekasi Utara, and Bekasi Selatan.

\section{REFERENCES}

1. Adubra, L., Savy, M., Fortin, S., Kameli, Y., Kodjo, N., Fainke, K., Martin-Prevel, Y. (2019). The Minimum Dietary Diversity for Women of Reproductive Age (MDDW) Indicator Is Related to Household Food Insecurity and Farm Production Diversity: Evidence from Rural Mali. Current Developments in Nutrition, 3. https://doi.org/10.1093/cdn/nzz002

2. Amugsi, D. A., Dimbuene, Z. T., Bakibinga, P., Kimani-murage, E. W., Haregu, T. N., \& Mberu, B. (2016). Dietary diversity, socioeconomic status and maternal body mass index ( $B M I)$ : quantile regression analysis of nationally representative data from Ghana, Namibia and Sao Tome and Principe. https://doi.org/10.1136/bmjopen2016-012615

3. Arimond, M., Torheim, L. E., \& Joseph, M. (2009). Dietary Diversity as a Measure of the Micronutrient Adequacy of Women's Diets: Results from Rural Bangladesh Site. Washington DC.

4. Caut, C., Leach, M., \& Steel, A. (2020). Dietary guideline adherence during preconception and pregnancy: A systematic review. Maternal \& Child Nutrition, 16(2), e12916. https://doi.org/10.1111/mcn.12916

5. Cindy Fariski, Fillah Fithra Dieny, $H$. S. W. (2020). Kualitas Diet, Status Gizi dan Status Anemia Wanita Prakonsepsi Antara Desa dan Kota. Journal of the Indonesian Nutrition Association, 43(1), 11-24. https://doi.org/10.36457/gizindo.v

6. Custodio, E., \& Kayitakire, F. (2015). Exploring the new indicator Minimum Dietary Diversity-Women Results from Burkina Faso. https://doi.org/10.2788/860238

7. Dessie, Z. B., Fentie, M., Abebe, Z., Ayele, T. A., \& Muchie, K. F. (2019). Maternal characteristics and nutritional status among $6-59$ months of children in Ethiopia: further analysis of demographic and health survey, 1-10.

8. Elodie Becquey, G. C. and Y. M.-P. (2009). Dietary Diversity as a Measure of the Micronutrient Adequacy of Women's Diets: Results from Ouagadougou, Burkina Faso Site. Washington DC.

9. FAO and FHI 360. (2016). Minimum Dietary Diversity for Women A Guide to Measurement. Rome: FAO.

10. Fitriani, H., R, A. S., \& Nurdiana, P. (2020). Risk Factors of Maternal Nutrition Status During Pregnancy to Stunting in Toddlers Aged 12 - 59 Months, 8(2), 183-191.

11. Gina Kennedy, T. B. and M. D. (2013). Guidelines for measuring household and individual dietary diversity. Rome, Italy.

12. Kementerian Kesehatan Republik Indonesia. (2018). Hasil Utama Riset Kesehatan Dasar 2018. Jakarta, Indonesia.

13. Kementerian Kesehatan Republik Indonesia. (2019). Peraturan Menteri Kesehatan Ri No.28 Tahun 2019 Tentang Angka Kecukupan Gizi.

14. Kementrian Kesehatan Republik 
Indonesia. (2013). Riset Kesehatan Dasar 2013.

15. Kementrian Kesehatan Republik Indonesia. (2014). Pedoman Gizi Seimbang. Jakarta, Indonesia.

16. Kpewou, D. E., Wieringa, F. T., \& Berger, J. (2020). Maternal mid-upper arm circumference during pregnancy and linear growth among Cambodian infants during the first months of life, 16 (January), 1-11. https://doi.org/10.1111/mcn.12951

17. Krawinkel, M., \& Habte, T. (2017). Dietary Diversity Score: A Measure of Nutritional Adequacy or an Indicator of Dietary Diversity Score: A Measure of Nutritional Adequacy or an Indicator of Healthy Diet? Journal of Nutrition and Health Sciences, Vol. 3(Issue https://doi.org/10.15744/23939060.3.303

18. Mahmood, T., Rehman, A. U. R., Tserenpil, G., Siddiqui, F., \& Ahmed, M. (2019). The Association between Iron-deficiency Anemia and Adverse Pregnancy Outcomes : A Retrospective Report from Pakistan Conclusion:, 11(10). https://doi.org/10.7759/cureus.5854

19. Martin, J. C., Moran, L. J., Teede, H. J., Ranasinha, S., Lombard, C. B., \& Harrison, C. L. (2017). Exploring Diet Quality between Urban and Rural Dwelling Women of Reproductive Age. Nutrients, 9(6). https://doi.org/10.3390/nu9060586

20. Nguyen, P., Ramakrishnan, U., Katz, B., Gonzalez-casanova, I., Alyssa, E., Nguyen, H., ... Martorell, R. (2014). Mid-upper-arm and calf circumferences are useful predictors of underweight in women of reproductive age in northern Vietnam, $35(3)$.

https://doi.org/10.1177/15648265140 3500303

21. Nithya, D. J., \& Bhavani, R. V. (2018). Dietary Diversity and Its Relationship with Nutritional Status Among
Adolescents and Adults in Rural India. Journal of Biosocial Science, 50(3), 397-413.

https://doi.org/10.1017/S0021932017 000463

22. Reski, R. N., Hadju, V., Indriasari, R., \& Muis, M. (2020). Anemia, chronic energy deficiency and their relationship in preconception women. Enfermería Clínica, 30, 76-80. https://doi.org/https://doi.org/10.1016 j.enfcli.2020.06.018

23. Restu, S., Sumiaty, S., Irmawati, I., \& Sundari, S. (2017). Relationship of Chronic Energy Deficiency in Pregnant Women with Low Birth Weight Newborn in Central Sulawesi Province, 4531, 252-259.

24. Siega-Riz, A. M., Vladutiu, C. J., Butera, N. M., Daviglus, M., Gellman, M., Isasi, C. R., ... Sotres-Alvarez, D. (2020). Preconception Diet Quality Is Associated with Birth Weight for Gestational Age Among Women in the Hispanic Community Health Study/Study of Latinos. Journal of the Academy of Nutrition and Dietetics. https://doi.org/10.1016/j.jand.2020.09 .039

25. Tang, A. M. (2013). Use of Cutoffs for Mid-Upper Arm Circumference ( MUAC) as an Indicator or Predictor of Nutritional and Health- Related Outcomes in Adolescents and Adults: A Systematic Review, (November).

26. Weerasekara, P. C., Withanachchi, C. R., Ginigaddara, G. A. S., \& Ploeger, A. (2020). Understanding Dietary Diversity, Dietary Practices and Changes in Food Patterns in Marginalised Societies in Sri Lanka. Foods (Basel, Switzerland), 9(11). https://doi.org/10.3390/foods9111659

27. WHO. (2011). Haemoglobin concentrations for the diagnosis of anaemia and assessment of severity. Vitamin and Mineral Nutrition Information System, 1-6.

28. World Health Organization. Regional Office for the Western Pacific. (2000). 
The Asia-Pacific perspective: redefining obesity and its treatment. Sydney: Health Communication Australia. https://doi.org/0-95770821-1

29. Yahia, E. M., García-Solís, P., \& Celis, M. E. M. (2019). Chapter 2 -
Contribution of Fruits and Vegetables to Human Nutrition and Health. In E. M. B. T.-P. P. and B. of F. and V. Yahia (Ed.) (pp. 19-45). Woodhead Publishing.

https://doi.org/https://doi.org/10.1016 /B978-0-12-813278-4.00002-6 